\title{
Models for Predicting the Lower Limit of the Canopy-Air Temperature Difference of Two Cool Season Grasses
}

\author{
D. L. Martin, D. J. Wehner, ${ }^{*}$ and C. S. Throssell
}

\begin{abstract}
Estimation of the lower limit of the canopy-air temperature differential, $\left(T_{c} \cdot T_{a}\right)_{L 1}$, is required for calculation of an empirically-based crop water stress, index. This research determined the complexity of model needed for accurate estimation of $\left(T_{c}-T_{a}\right)_{L L}$ for several field grown cultivars of Kentucky bluegrass (Poa pratensis L.) and for creeping bentgrass (Agrostis stolonifera L. var. palustris (Huds.) Farw.). Regression models using vapor pressure deficit of the air (VPD), net radiation load $\left(R_{n}\right)$, and wind speed (WS) were developed for predicting $\left(T_{c}-T_{2}\right)_{L L}$. The best one to three-variable regression models for predicting $\left(T_{c}-T_{a}\right)_{L L}$ used variable groups of VPD $\left(r^{2}=0.47\right)$; VPD and $R_{\mathrm{n}}\left(R^{2}=0.66\right)$; and VPD, $R_{n}$, and WS $\left(R^{2}=0.82\right)$. Models developed for predicting $\left(T_{c}-T_{n}\right)_{L L}$ on individual Kentucky bluegrass cultivars, across Kentucky bluegrass, and across both species were tested on a validation data set. Models using only VPD accounted for $<2 \%$ of variation in actual $\left(T_{C}-T_{a}\right)_{L L}$ of nonwater-stressed turf. Models using VPD and $R_{\mathrm{n}}$ developed from pooled Kentucky bluegrass data, individual Kentucky bluegrass cultivars, or Kentucky bluegrass and creeping bentgrass data accounted for an average of 15,13 , and $14 \%$ of variation in actual $\left(T_{c}-T_{a}\right)_{1 . L}$, while models using VPD, $R_{n}$, and WS accounted for an average of 62,62 , and $64 \%$, respectively. On creeping bentgrass, the Kentucky bluegrass model and dual species model introduced a large amount of bias to predicted $\left(T_{c}-T_{n}\right)_{L L}$. At sites where environmental conditions are highly variable, the effects of VPD, $R_{n}$, and WS must be taken into account to accurately predict $\left(T_{c}-T_{u}\right)_{1,1}$ of turfgrass. $A$ single model appears appropriate for prediction of $\left(T_{c}-T_{H}\right)_{L L}$ across Kentucky bluegrass cultivars; a separate model for creeping bentgrass is required.
\end{abstract}

A S DEMANDs on potable water resources continue to increase it is imperative that all uses of this resource become more efficient. Turfgrass managers often

D.L. Martin, Dep. Horticulture and Landscape Architecture, Oklaboma State Univ., Stillwater, OK 74078-0511; D.J. Wehner, Dep. of Horliculture, Univ. of Itlinois, 120 I S. Dorner Dr., Urbann, IL 61801; and C.S. Throssell, Dep. of Agronomy, Purdue Univ., West Lafayete, IN 47907. Contribution of the Illinois Agric. Exp. Stn. Received 24 Aug. 1992. " Corresponding author.

Published in Crop Sci. 34:192-198 (1994). face restrictions on the amount of water available for irrigation. Thus, it is critical that they utilize practices that optimize the timing and amount of irrigation applied to an area.

Carrow (1985) grouped turfgrass irrigation programming techniques into four categories: (i) techniques that determine when to irrigate based on soil moisture status, (ii) techniques that use meterological data to determine plant-water requirements, (iii) techniques that determine plant-water status, or (iv) techniques that utilize a combination of the above methods. A subgroup of plantwater status techniques referred to as canopy-temperature based techniques have received increased attention in the literature. One of these methods, known as the Crop Water Stress Index (CWSI) method (Jackson et al., 1981; Idso et al., 1981a,b) was found to have potential in scheduling irrigation of turfgrasses by Throssell et al. (1987). They compared the empirical CWSI method to the stress-degree-day method, irrigation scheduling using a tensiometer, and the critical-point method.

The empirical CWSI method is based on determining the difference in canopy vs. air temperature $\left(T_{c}-T_{a}\right)$, adjusting the difference for current meteorological conditions that affect the $T_{c}$, and then comparing the difference with what would be expected for nonwater stressed plants to generate a CWSI. A detailed discussion of the theory behind the limitations to the CWSI method and its relationship to turfgrass water status has been presented by Martin (1990).

The empirical CWSI method requires determination of the lower and upper limits, referred to as baselines, of $\left(T_{c}-T_{i}\right)$. The lower limit of $\left(T_{c}-T_{i 1}\right)$ is determined on nonwater-stressed turf. Horst et al. (1989), working in Texas with three warm season and one cool season turfgrass (tall fescue, Festuca anundinacea Schreb.), found that when $\left(T_{c}-T_{i l}\right)_{t .1}$ was plotted as a function of VPD,

Abbreviations: $\left(T_{c}-T_{1}\right)_{1,}$, lower limit of canopy minus air temperature difference; $V \mathrm{PD}$, vapor pressure deficit; $R_{n}$, net radiation load; WS, wind speed; CWSI, crop witer stress index;

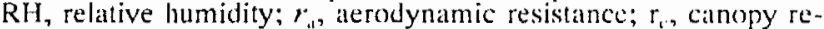
sistance. 
the bascline slopes were seasonally as well as species dependent. Earlier work by Horst et al. (1987) suggested that the aerodynamic and canopy resistances associated with turfgrass stands may be species as well as mowing height specific, and thus, a general nonwater-stressed baseline may need modification for each turfgrass under each different cultural regime.

The purpose of this research project was to determine the complexity of model needed to accurately predict the $\left(T_{c}-T_{a}\right)_{L L}$ for turfgrass growing in Illinois and to determine if a single $\left(\mathrm{T}_{c}-\mathrm{T}_{a}\right)_{L L}$ model is appropriate for calculating CWSI values for both Kentucky bluegrass and creeping bentgrass.

\section{MATERIALS AND METHODS}

The experiment was conducted at the University of Illinois Ornamental Horticulture Research Center, Urbana, IL. Research was conducted on single plots of 'Penncross' and several Kentucky bluegrass cultivars growing on a Flanagan silt loam (fine, montmorillonitic, mesic aquic argiudoll). The Kentucky bluegrass used were 'South Dakota Common', "America,' 'Kenblue,' 'Bristol,' and a blend of 'Adelphi,' 'Glade,' 'Parade,' and 'Rugby.' Plot size was 5.2 by $5.2 \mathrm{~m}$.

In 1988, all grasses were fertilized on 3 June, 5 August, and 7 November with 84,48 , and $48 \mathrm{~kg} \mathrm{~N}^{-1}$, respectively. In $1989,48 \mathrm{~kg} \mathrm{~N}^{-1}$ were applied to all grasses on 18 May, 20 June, $18 \mathrm{July}$, and 12 October. Mowing was performed two to three times per week as needed at a height of $48 \mathrm{~mm}$ for Kentucky bluegrass and every other day at $9.5 \mathrm{~mm}$ for creeping bentgrass. Clippings were returned for all grasses.

Water was applied by irrigation to maintain turfgrass evapotranspiration at full potential (nonlimiting soil moisture conditions) for the prevailing environmental conditions. Water was applied to all plots when soil matric potentials of any plot fell below $-0.04 \mathrm{MPa}$. Soil matric potentials were monitored by tensiometers installed at a $5.1-\mathrm{cm}$ depth under Kentucky bluegrass and a $2.5-\mathrm{cm}$ depth under creeping bentgrass. Water was applied in a quantity that brought tensiometer readings to 0 $\mathrm{MPa}$. No meteorological data was sampled from turf when tensiometers measurcd $0 \mathrm{MPa}$ or when tensiometer values fell below $-0.04 \mathrm{MPa}$.

Canopy temperature of the turfgrass was measured with an infrared thermometer (ST 27 Turfgrass Monitor, Carborundum Co., Solon, OH) with a six-degree field of view. The emissivity setting on the instrument was factory set at 0.99 . Twelve $\mathrm{T}_{c}$ readings were taken at 5 -s intervals during a 1 -min measuring period (six west facing, six east facing) and averaged to provide a mean for the sampling period. The infrared thermometer was held $1.3 \mathrm{~m}$ above the turf at an angle of $40^{\circ}$ from horizontal providing a target area of $\approx 0.05 \mathrm{~m}^{2}$.

Air temperature and relative humidity (RH) were measured by an aspirated bead thermistor and an aspirated capacitancetype humidity sensor located in the nose of the infrared thermometer. Sampling of $\mathrm{T}_{\mathrm{a}}$ and $\mathrm{RH}$ was performed at the same time and frequency as $T_{c}$ sampling, with averages calculated for each sampling period.

Wind speed was measured over each plot using a three-cup anemometer (R.M. Young Company, Traverse City, MI) positioned at a height of $1.5 \mathrm{~m}$ above the canopy. Net radiation load was measured for each plot using a Fritschen type miniature net radiometer (Fritschen and Mulling, 1965) positioned $1 \mathrm{~m}$ above the canopy. Voltage outputs from the anemometer and net radiometer were measured every $5 \mathrm{~s}$ and averaged for each 1-min sampling period by data logger (Model LI-1000, LICOR, Lincoln, NE).

Thrce to four 1 -min measuring periods were conducted on each plot between 1200 and $1500 \mathrm{~h}$ on 17 dates in 1988 and 31 dates in 1989. Meteorological conditions were variable among the dates, however, data were taken only when solar radiation conditions were stable. Data from 17 dates in 1988 and 16 dates in 1989 were pooled to form Data Set I for construction of models to predict $\left(\mathrm{T}_{c}-\mathrm{T}_{\mathrm{il}}\right)_{\mathrm{LL}}$ of turf. Regression analysis was performed in order to relate $\left(T_{c}-T_{i}\right)$ to environmental variables such as the (VPD), $R_{n}$, and WS. Linear additive equations were investigated.

In order to use the complete energy balance equation to predict $\left(\mathrm{T}_{c}-\mathrm{T}_{\mathrm{a}}\right)_{\mathrm{LL}}$, estimates of the aerodynamic resistance $\left(r_{i}\right)$ and the canopy resistance $\left(r_{c}\right)$ of the turf were required. Values of $r$ for the turf canopies were determined by a method similar to that used by Johns et al. (1983) utilizing the resistance to enthalpy loss by a completely wetted canopy. Turf was sprayed with a 1:200 mixture of wetting agent/water ( $\mathrm{Hy}$ draflo, Sierra Crop Protection Co., Milpitas, CA) in a quantity to ensure complete wetting. A delay between canopy wetting and the measurement period was practiced to allow for canopy temperature stabilization. The wetting procedure was performed for each 1-min sampling period. Sampling was performed on seven dates in 1988 and nine dates in 1989. Attempts were made to sample during periods that would provide a broad range of WS to the data set (Data Set II). The energy balance equation used by Jackson et al. (1981) was rearranged to solve for $r_{\mathrm{a}}$ when $r_{\mathrm{c}}$ is zero (the case of a completely wetted canopy):

$$
r_{\mathrm{a}}=\left[\left(\mathrm{T}_{\mathrm{c}}-\mathrm{T}_{\mathrm{a}}\right)+\mathrm{VPD} /(\Delta+\gamma)\right](\Delta+\gamma)\left(\rho \mathrm{C}_{\mathrm{p}} / \gamma R_{\mathrm{n}}\right) .
$$

In Eq. [1], $r_{\mathrm{a}}=$ the aerodynamic resistance in seconds per meter, $\Delta=$ the slope of the saturation vapor pressure with temperature relationship $\left(\mathrm{kPa}{ }^{\circ} \mathrm{C}^{-1}\right)$ with $\Delta$ calculated at $\left(\mathrm{T}_{\mathrm{c}}\right.$ $\left.+\mathrm{T}_{\mathrm{i}}\right) / 2, \gamma=$ the psychrometric constant $\left(\mathrm{kPa}{ }^{\circ} \mathrm{C}^{-1}\right), \rho=$ the density of air $\left(\mathrm{g} \mathrm{m}^{-3}\right)$, and $\mathrm{C}_{\mathrm{p}}=$ the heat capacity of air $\left(\mathrm{J} \mathrm{g}^{-1}{ }^{\circ} \mathrm{C}^{-1}\right)$. Values of $r_{\mathrm{a}}$ were regressed on the $\log _{10}$ transformation of WS in order to develop equations for predicting $r_{\mathrm{a}}$ as function of WS for each cultivar or species.

To elucidate the relationship between $r_{c}$ and $R_{n}$ for the nonwater stressed grasses, $T_{c}$ and associated meteorological parameters were sampled for two 1-min measuring periods per hour per plot on five dates in 1988 and 10 dates in 1989. Sampling was performed from shortly before sunrise to shortly after sunset provided skies were clear. Samples taken when dew was present or when tensiometer readings fell below -0.04 MPa were discarded. In addition to the data gathered on these 15 dates, data from 10 dates from Data Set I were included in the data set (Data Set III). Values of $r_{\mathrm{c}}\left(\mathrm{s} \mathrm{m}^{-1}\right)$ were calculated by the rearranged energy balance equation:

$$
\begin{gathered}
r_{\mathrm{c}}=r_{\mathrm{a}}\left[\gamma_{\mathrm{a}} R_{\mathrm{n}} /\left(\rho \mathrm{C}_{\mathrm{p}}\right)-\left(\mathrm{T}_{\mathrm{c}}-\mathrm{T}_{\mathrm{a}}\right)(\Delta+\gamma)-\mathrm{VPD}\right] / \\
{\left[\gamma\left(\left(\mathrm{T}_{\mathrm{c}}-\mathrm{T}_{\mathrm{a}}\right)-r_{\mathrm{a}} R_{\mathrm{n}} /\left(\rho \mathrm{C}_{\mathrm{p}}\right)\right)\right]}
\end{gathered}
$$

Values of $r_{\mathrm{a}}$ required in Eq. [2] were estimated by the regression relationships between $r_{\mathrm{a}}$ and WS. To develop a prediction equation relating $r_{\mathrm{c}}$ (calculated by Eq. [2]) to $R_{\mathrm{n}}$, the $\log _{10}$ transformation of $r_{\mathrm{c}}$ was regressed on the $\log _{10}$ additively transformed $R_{\mathrm{n}}$. Since $R_{\mathrm{n}}$ remained negative in sign shortly after sunrise and became negative again shortly before sunset, an additive transformation of $R_{\mathrm{n}}\left(+100 \mathrm{~W} \mathrm{~m}^{-2}\right)$ was performed prior to $\log _{10}$ transformation in order to avoid taking the logarithm of a negative number.

An independent data set (Data Set IV) was constructed from data gathered from nonwater-stressed turf between 1200 and $1500 \mathrm{~h}$ on 15 of the 31 sampling dates (previously discussed) in 1989. The best one, two, and three-variable empirical models fit to $T_{c}-T_{a}$ from Data Set 1 as well as the complete energy balance approach were tested for their ability to predict $\left(\mathrm{T}_{c}-\right.$ $\left.\mathrm{T}_{\mathrm{a}}\right)_{\mathrm{LL}}$ of nonwater-stress turf. An iterative procedure described by Jackson et al. (1981) was used to generate the predicted $\mathrm{T}_{\mathrm{c}}$ and $\Delta$ at full potential evapotranspiration, as these variables were treated as unknowns. Actual $\mathrm{T}_{c}-\mathrm{T}_{\mathrm{a}}$ from Data Set IV was regressed on the predicted $\left(T_{c}-T_{a}\right)_{L L}$ from all equations being tested. Values of $R^{2}$ as well as slopes of the fitted lines were used as evaluation criteria. 
Table 1. Summary of vapor pressure deficit (VPD), net radiation $\left(R_{\mathrm{n}}\right)$, and windspeed (WS) statistics for data sets gathered during the 1988 and 1989 sampling periods.

\begin{tabular}{|c|c|c|c|c|c|c|c|c|c|c|c|c|}
\hline & \multirow[b]{2}{*}{ Data set } & \multirow[b]{2}{*}{ Year } & \multirow[b]{2}{*}{$n$} & \multicolumn{3}{|c|}{ VPD } & \multicolumn{3}{|c|}{$R_{n}$} & \multicolumn{3}{|c|}{ WS } \\
\hline & & & & $\begin{array}{l}\text { Mini- } \\
\text { mum }\end{array}$ & $\begin{array}{l}\text { Maxi- } \\
\text { mum }\end{array}$ & Mean & $\begin{array}{l}\text { Mini- } \\
\text { mum }\end{array}$ & $\begin{array}{l}\text { Maxi- } \\
\text { mum }\end{array}$ & Mean & $\begin{array}{l}\text { Mini- } \\
\text { mum }\end{array}$ & $\begin{array}{l}\text { Maxi- } \\
\text { mumı }\end{array}$ & Mean \\
\hline & & & & \multicolumn{3}{|c|}{$\mathrm{kPa}$} & \multicolumn{3}{|c|}{$W m^{-2}$} & \multicolumn{3}{|c|}{$-\mathrm{ms} \mathrm{s}^{-2}$} \\
\hline I. & $\begin{array}{l}\text { Lower } \\
\text { baseline }\end{array}$ & $\begin{array}{l}1988 \\
1989\end{array}$ & $\begin{array}{l}391 \\
285\end{array}$ & $\begin{array}{l}0.84 \\
0.69\end{array}$ & $\begin{array}{l}4.74 \\
2.41\end{array}$ & $\begin{array}{l}2.69 \\
1.40\end{array}$ & $\begin{array}{r}101.9 \\
83.3\end{array}$ & $\begin{array}{l}752.1 \\
779.6\end{array}$ & $\begin{array}{l}419.3 \\
476.1\end{array}$ & $\begin{array}{l}0.20 \\
0.20\end{array}$ & $\begin{array}{l}8.08 \\
8.30\end{array}$ & $\begin{array}{l}2.96 \\
3.03\end{array}$ \\
\hline II. & $\begin{array}{l}\text { Canopy } \\
\text { resistance }\end{array}$ & $\begin{array}{l}1988 \\
1989\end{array}$ & $\begin{array}{l}541 \\
416\end{array}$ & $\begin{array}{l}0.38 \\
0.45\end{array}$ & $\begin{array}{l}4.69 \\
2.33\end{array}$ & $\begin{array}{l}2.38 \\
1.28\end{array}$ & $\begin{array}{l}-58.3 \\
-61.5\end{array}$ & $\begin{array}{l}694.5 \\
683.5\end{array}$ & $\begin{array}{l}387.2 \\
331.9\end{array}$ & $\begin{array}{l}0.32 \\
0.20\end{array}$ & $\begin{array}{l}8.08 \\
5.55\end{array}$ & $\begin{array}{l}2.77 \\
2.49\end{array}$ \\
\hline III. & $\begin{array}{l}\text { Aerodynamic } \\
\text { resistance }\end{array}$ & $\begin{array}{l}1988 \\
1989\end{array}$ & $\begin{array}{l}279 \\
424\end{array}$ & $\begin{array}{l}0.99 \\
0.49\end{array}$ & $\begin{array}{l}4.71 \\
1.98\end{array}$ & $\begin{array}{l}2.42 \\
1.25\end{array}$ & $\begin{array}{l}116.5 \\
169.2\end{array}$ & $\begin{array}{l}650.7 \\
615.5\end{array}$ & $\begin{array}{l}433.5 \\
382.7\end{array}$ & $\begin{array}{l}0.25 \\
0.20\end{array}$ & $\begin{array}{l}8.07 \\
5.61\end{array}$ & $\begin{array}{l}4.25 \\
2.39\end{array}$ \\
\hline IV. & $\begin{array}{l}\text { Independent } \\
\text { data set }\end{array}$ & 1989 & 260 & 0.49 & 2.63 & 1.56 & 138.0 & 708.2 & 483.5 & 0.20 & 9.13 & 2.87 \\
\hline
\end{tabular}

\section{RESULTS AND DISCUSSION}

\section{Predicting the Lower Limit of the Canopy-Air Temperature Difference of Turf}

A summary of the meteorological conditions prevailing during measurement periods for the five data sets are shown in Table 1 . A wide range of observed VPD, $R_{\mathrm{n}}$, and WS were present. Such conditions were desirable when developing prediction equations in order to reduce the probability of biasing the models toward a specific set of environmental conditions.

The coefficients of determination of models fit to $T_{c}$ - $T_{a}$ of the various grasses (Table 2 and 3 ) increased with increasing model complexity. When a single independent variable was considered, VPD provided the best fit with an average $r^{2}=0.47$, compared with 0.10 and 0.12 for equations containing $R_{\mathrm{n}}$ or WS, respectively. The average correlation coefficients between $\mathrm{T}_{\mathrm{c}}-\mathrm{T}_{\mathrm{a}}$ of nonwater-stressed turf and VPD, $R_{n}$, and WS were -0.68 , 0.32 , and -0.34 , respectively. Models containing VPD $+R_{\mathrm{n}}$ accounted for more variation than those containing VPD + WS, with the average $R^{2}$ values being 0.66 and 0.54 , respectively. The actual coefficients and intercepts for the three-variable models are shown in Table 3 . The three-variable linear model containing VPD $+R_{\mathrm{n}}+\mathrm{WS}$ had an average $R^{2}$ value of 0.82 . Values of $R^{2}$ varied little between equations that were fit to data pooled across all grasses or just across Kentucky bluegrass cultivars. In general, $R^{2}$ values from equations fit to data pooled across all grasses were intermediate to those fit to data from individual grasses.

Based on coefficient of determination values of empirical equations fit to $T_{c}-T_{a}$ of nonwater-stressed turf, the most sound progression in model complexity from one through three variables was to utilize the variable groups VPD; VPD and $R_{\mathrm{n}}$; and VPD, $R_{\mathrm{n}}$, and WS. As discussed later, these three forms of linear equations were tested for predictive capability of an independent data set.

In work performed in Texas on nonwater-stressed bermudagrass [Cynodon dactylon (L.) Pers.], St. Augustinegrass (Stenotaphrum secundatum (Walker) O. Kuntze), tall fescue, and buffalograss [Buchloe dactyloides (Nutt.) Engelm.], Horst et al. (1989) found VPD, $R_{\mathrm{n}}$, and WS to account for an average of 53,16 , and $7 \%$, respectively, (76\% tolal) of variation in $\mathrm{T}_{c}-\mathrm{T}_{\mathrm{a}}$ using multiple additive regression equations. Utilizing the same com- plexity of model, we found VPD, WS, and $R_{\mathrm{n}}$ to explain an average of 46,17 , and $18 \%$, respectively, ( $81 \%$ total) of variation in $T_{c}-T_{a}$ of the six nonwater-stressed turfgrass examined. Whereas the range of WS and the magnitude of the range in VPD measured by Horst et al. (1989) and in our work were similar, VPD measured in our study was generally lower. The range of $R_{\mathrm{n}}$ in this study was 83 to $779 \mathrm{~W} \mathrm{~m}^{-2}$ (Table 1) compared with $\approx 400$ to $700 \mathrm{~W} \mathrm{~m}^{-2}$ for the work of Horst et al. (1989). The larger range of $R_{\mathrm{n}}$ in this study may be responsible for $R_{\mathrm{n}}$ having a more equal role with WS in accounting for the variation in $T_{c}-T_{a}$.

The complete energy-balance equation suggests VPD, $R_{n}$, and WS to be important in influencing $\mathrm{T}_{c}-\mathrm{T}_{\mathrm{a}}$ of transpiring turf. Although WS does not appear explicitly in the energy-balance approach as does VPD and $R_{\mathrm{n}}$, it does affect $r_{\mathrm{a}}$ of the canopy. It is likely that the relative importance of VPD, $R_{\mathrm{n}}$, and WS in empirical models for predicting $T_{c}-T_{a}$ is closely linked to the total range of the three variables measured during the periods of data acquisition.

\section{Predicting Aerodynamic Resistance of Turf}

The equations and resulting curves generated for each of the six turfgrasses by regression of predicted $r_{\mathrm{a}}$ and the $\log _{10}$ transformation of WS are presented in Fig. 1 . Due to the large number of $r_{\mathrm{a}}$ samples taken, display of

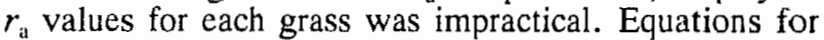
all grasses were highly significant. Values of $r^{2}$ ranged from a high of 0.77 for Penncross creeping bentgrass to a low of 0.57 for South Dakota Common Kentucky bluegrass.

The range of slopes for Kentucky bluegrass cultivars was from -57.3 for South Dakota Common to -75.3 for Kenblue. The slope of the line fit to data from creeping bentgrass was -75.6 . The intercept for creeping bentgrass, $100.0 \mathrm{~s} \mathrm{~m}^{-1}$, was considerably larger than those of equations fit to Kentucky bluegrass cultivars which ranged from 79.3 to $90.9 \mathrm{~s} \mathrm{~m}^{-1}$.

Aerodynamic resistance decreased with increasing WS. Creeping bentgrass demonstrated a greater predicted $r_{i n}$ than any of the Kentucky bluegrass cultivars across the range of WS measured in this study. Creeping bentgrass cut at $9.5 \mathrm{~mm}$ would be expected to have a higher $r_{\text {a }}$ than Kentucky bluegrass cut at $48 \mathrm{~mm}$ due to a smoother canopy surface. 
Table 2. Summary of $r^{2}$ and $R^{2}$ values for equations fitted to the canopy-air temperature differential of nonwater-stressed Kentucky bluegrass and creeping bentgrass.

\begin{tabular}{|c|c|c|c|c|c|c|c|c|}
\hline $\begin{array}{l}\text { Variables } \\
\text { in model }\end{array}$ & $\begin{array}{c}\text { Blendt } \\
\text { Kentucky } \\
\text { bluegrass }\end{array}$ & $\begin{array}{c}\text { South } \\
\text { Dakota } \\
\text { Kentucky } \\
\text { bluegrass }\end{array}$ & $\begin{array}{l}\text { America } \\
\text { Kentucky } \\
\text { bluegrass }\end{array}$ & $\begin{array}{l}\text { Kenblue } \\
\text { Kentucky } \\
\text { bluegrass }\end{array}$ & $\begin{array}{c}\text { Bristol } \\
\text { Kentucky } \\
\text { bluegrass }\end{array}$ & $\begin{array}{c}\text { Penncross } \\
\text { creeping } \\
\text { bentgrass }\end{array}$ & $\begin{array}{c}\text { All } \\
\text { grasses } \\
\text { pooled }\end{array}$ & $\begin{array}{c}\text { Kentucky } \\
\text { bluegrasses } \\
\text { pooled }\end{array}$ \\
\hline $\begin{array}{l}\text { Vapor pressure } \\
\text { deficit (VPD) }\end{array}$ & $0.34^{* *}$ & $0.31 * *$ & $0.47^{* *}$ & $0.42^{* *}$ & $0.64 * *$ & $0.60^{* *}$ & $0.47^{* *}$ & $0.45 * *$ \\
\hline Net radiation $\left(R_{n}\right)$ & $0.21 * *$ & $0.18^{* *}$ & $0.03^{*}$ & $0.06^{* *}$ & $0.04^{*}$ & $0.10^{* *}$ & $0.10^{* * *}$ & $0.10^{* *}$ \\
\hline Wind speed (WS) & $0.07^{* *}$ & $0.08^{* * *}$ & $0.13^{* *}$ & $0.16^{* *}$ & $0.15^{* *}$ & $0.11^{* *}$ & $0.12 * *$ & $0.12^{* *}$ \\
\hline$V P D+W S$ & $0.40^{* * *}$ & $0.36^{* *}$ & $0.52 * *$ & $0.56^{* * *}$ & $0.68 * *$ & $0.64^{* *}$ & $0.54^{* *}$ & $0.52^{* * *}$ \\
\hline $\mathrm{VPD}+R_{\mathrm{n}}$ & $0.63^{* *}$ & $0.57^{* *}$ & $0.63^{* *}$ & $0.58^{* *}$ & $0.76^{* *}$ & $0.73^{* *}$ & $0.66^{* *}$ & $0.65 * *$ \\
\hline
\end{tabular}

*,** Significant at 0.05 and 0.01 probability levels respectively.

$\dagger$ The blend consisted of Adelphi, Glade, Parade, and Rugby Kentucky bluegrasses.

Predicted $r_{\mathrm{a}}$ varied among the Kentucky bluegrass cultivars. Relative ranking of the Kentucky bluegrass cultivars by magnitude of predicted $r_{\text {a }}$ varied with WS. The curves for predicted $r_{\mathrm{a}}$ suggest differences of $10 \mathrm{~s} \mathrm{~m}^{-1}$ may often be present among Kentucky bluegrass cultivars. Factors such as leaf and stem number as well as their position within the turfgrass canopy have been implicated in influencing $r_{\mathrm{a}}$. A turf with high leaf and stem densities plus substantial horizontal leaf orientation can cause greater impairment of normal upward movement of water vapor and sensible heat leading to a greater $r_{\mathrm{a}}$ (Beard, 1985). We did not characterize the canopy structure of the grasses utilized in this work.

Johns et al. (1983) found St. Augustinegrass to have mean $r_{\text {a }}$ values of 72,79 , and $66 \mathrm{~s} \mathrm{~m}^{-1}$ at a mean WS of $0.6 \mathrm{~m} \mathrm{~s}^{-1}$ when cut at heights of $5,6.5$, and $8 \mathrm{~cm}$, respectively. Direct comparison of these values to those found in our work is not appropriate because different species and mowing heights were used in the two studies. In addition, WS was measured at a height of 0.15 $\mathrm{m}$ above the turf in the study conducted by Johns et al. (1983) and at $1.5 \mathrm{~m}$ above the turf in this study. Wind speed varies with height of measuremnt above the plant canopy (Monteith, 1973). To predict $r_{\mathrm{z}}$ using our regression equations, WS should be measured at $1.5 \mathrm{~m}$ or adjustments to the predicted $r_{\mathrm{a}}$ will be necessary.

\section{Predicting Canopy Resistance of Turf}

The curves and equations generated by regression of $\log _{10}$ transformation of $r_{\mathrm{c}}$ on $\log _{10}$ transformation of $\left(R_{\mathrm{n}}\right.$ $+100 \mathrm{~W} \mathrm{~m}^{-2}$ ) are shown in Fig. 2. The form of the equation was $r_{\mathrm{c}}=10^{\mathrm{b}}\left(R_{\mathrm{n}}+100\right)^{\mathrm{a}}$, where $b$ and $a$ are the intercept and slope terms after $\log _{10}$ transformation of dependent and independent variables. The equation used to describe the relationship between $R_{\mathrm{n}}$ and $r_{\mathrm{c}}$ was similar to that used by Denmead and Millar (1976) to relate net irradiance with $r_{c}$ and by Hatfield (1985) to relate incoming shortwave radiation and $r_{c}$.

Variability in $r_{\mathrm{c}}$ accounted for by the regression equations ranged from $36 \%$ for creeping bentgrass to $62 \%$ for the Kentucky bluegrass blend. The $r^{2}$ values for our equations were lower than those reported in previous studies. The $r^{2}$ values for the references cited were based on data collected over a 1- (Hatfield, 1985) to 4-d period (Denmead and Millar, 1976), whereas we combined data over many dates during the growing season to develop a relationship predicting the seasonal average $r_{\mathrm{c}}$ at a given $R_{n}$. Under constant irradiance, the value of $r_{c}$ of a turfgrass would be expected to cycle between a maximum value immediately following mowing to a minimum value immediately preceding mowing. Mowing reduces the leaf transpirational area which causes $r_{c}$ to increase (Shearman, 1985).

The slope and intercept for the equation fit to data from creeping bentgrass were smaller than for any of the Kentucky bluegrass. Predicted $r_{\mathrm{c}}$ of creeping bentgrass was lower than any of the Kentucky bluegrass cultivars at $R_{\mathrm{n}}$ below $\approx 160 \mathrm{~W} \mathrm{~m}-2$ (Fig. 2 ). Above this range, America Kentucky bluegrass had the lowest predicted $r_{c}$ of any of the six turfgrasses. The blend of Kentucky bluegrass exhibited the highest predicted $r_{\mathrm{c}}$ across the entire range of $R_{\mathrm{n}}$ measured in this study. Differences in predicted $r_{\mathrm{c}}$ between grasses appeared to be minimal un-

Table 3. Coefficients, intercepts, and $R^{2}$ values for three-variable, first-order equations relating vapor pressure deficit of the air (VPD), windspeed (WS) and net radiation load $\left(R_{\mathrm{n}}\right)$ to the canopy-air temperature deficit of six nonwater-stressed turfgrasses.

\begin{tabular}{|c|c|c|c|c|c|}
\hline \multirow[b]{2}{*}{ Turfgrass } & \multicolumn{3}{|c|}{ Coefficients } & \multirow[b]{2}{*}{ Intercept } & \multirow[b]{2}{*}{$R^{2}$} \\
\hline & VPD & WS & $R_{\mathrm{n}}$ & & \\
\hline Blend Kentucky bluegrass $\dagger$ & -1.83 & -0.74 & 0.01 & 1.73 & $0.80 * *$ \\
\hline South Dakota Common Kentucky bluegrass & -1.54 & -0.82 & 0.01 & 1.41 & $0.78^{* *}$ \\
\hline America Kentucky bluegrass & -1.80 & -0.70 & 0.01 & 1.91 & $0.77^{* *}$ \\
\hline Kenblue Kentucky bluegrass & -2.04 & -1.01 & 0.01 & 2.79 & $0.85^{* *}$ \\
\hline Bristol Kentucky bluegrass & -2.21 & -0.69 & 0.01 & 2.49 & $0.86^{* *}$ \\
\hline Penncross creeping bentgrass & -2.30 & -0.92 & 0.01 & 3.29 & $0.87 * *$ \\
\hline Pooled Kentucky bluegrass & -1.90 & -0.82 & 0.01 & 2.11 & $0.80^{* *}$ \\
\hline Pooled Kentucky bluegrass + creeping bentgrass & -1.97 & -0.83 & 0.01 & 2.32 & $0.81 * *$ \\
\hline
\end{tabular}

*** Significant at 0.01 probability level.

† The blend consisted of Adelphi, Glade, Parade, and Rugby Kentucky bluegrasses. 
der conditions of high $R_{\mathrm{n}}$ and maximal under very low $R_{\mathrm{n}}$.

As with $r_{\mathrm{a}}$, minimal information on actual measured $r_{\mathrm{c}}$ of turfgrasses is available in the literature. In work by Jolnns et al. (1981) on St. Augustinegrass, $r_{\mathrm{c}}$ averaged 14,22 , and $43 \mathrm{~s} \mathrm{~m}^{-1}$ at cutting heights of $8.0,6.5$, and $5 \mathrm{~cm}$, respectively. Incoming shortwave radiation supplied by a metal-halide source in the controlled environmental chamber utilized by Johns et al. (1981) averaged $300 \mathrm{~W} \mathrm{~m}^{-2}$. Comparison of the values measured by Johns et al. (1981) with our values is of limited usefulness, as different species and mowing heights were utilized as well as the fact that the spectrum of the metal-halide source varies from that of natural sun light.

\section{Validation of Prediction Equations}

Values of $r^{2}$ and slopes of equations generated by regression of actual $\left(T_{c}-T_{a}\right)_{L L}$ of nonwater-stressed turf from the independent data set on predicted $\left(T_{c}-\right.$ $\left.T_{i a}\right)_{L L}$ values for Kenblue Kentucky bluegrass and creeping bentgrass are shown in Table 4 . The models that were tested for predictive capability on the independent data set were the best one, two, and three-variable empirical models as well as the energy balance equation. For each Jevel of model complexity, there were three models tested; those developed from pooled Kentucky bluegrass data, from individual cultivars alone, and from
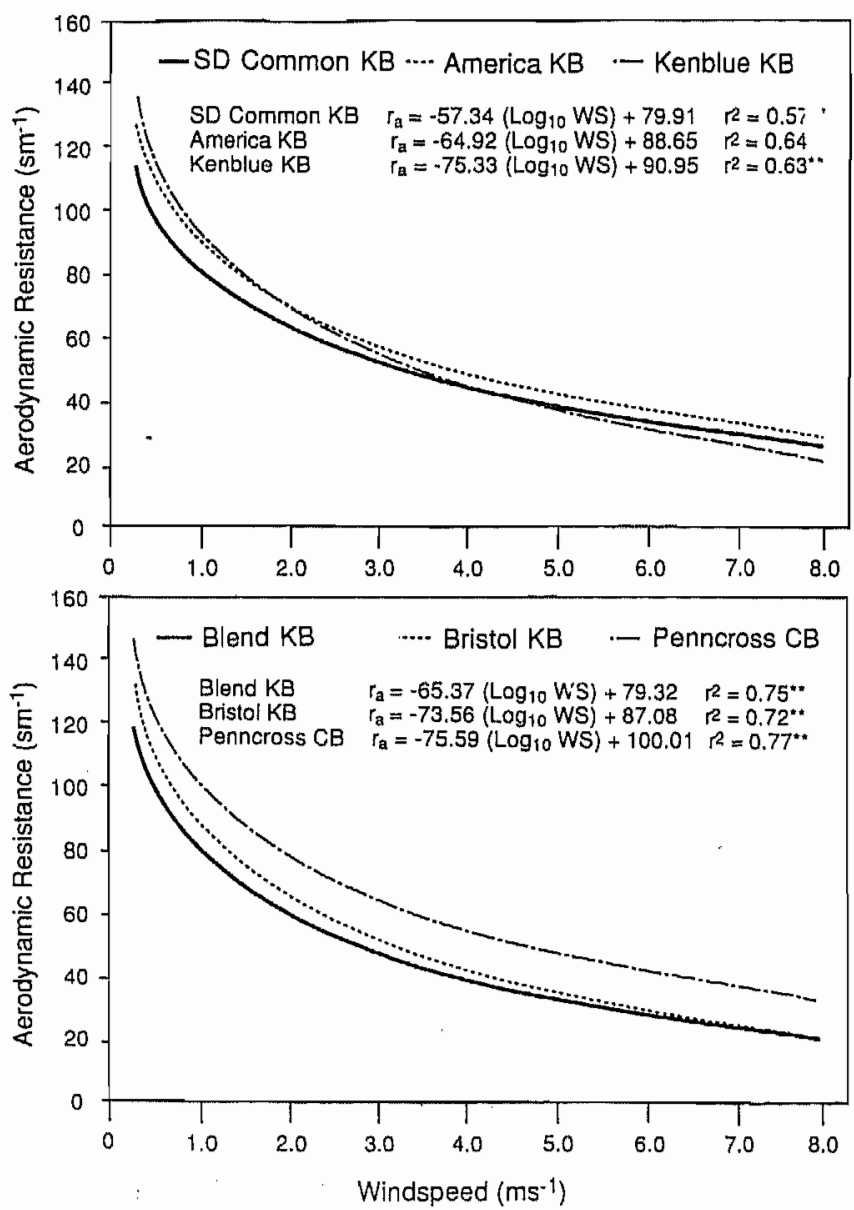

Fig. 1. Relationship between predicted aerodynamic resistance and windspeed for South Dakota Common Kentucky bluegrass (KB), America KB, Kenblue KB, a blend of KB, Bristol KB, and Penncross creeping bentgrass (CB). data pooled across all grasses. The energy balance approach utilized the crop specific components of $r_{\mathrm{a}}$ and $r_{\mathrm{c}}$ calculated by equations developed from the individual cultivar on which the model was being tested.

Models that utilized only VPD to predict $\left(T_{c}-T_{a}\right)_{L L}$ accounted for an inconsequential amount (from $<1$ to $2 \%$ ) of variation in actual $T_{c}-T_{a}$ and were not statistically significant at $P=0.05$. The two-variable models that were derived from pooled Kentucky bluegrass data, individual cultivar data, and data pooled across all grasses accounted for an average of 15,13 , and $14 \%$ of variation in actual $\left(T_{c}-T_{a}\right)_{L L}$. The relationships between actual $\left(T_{a}-T_{a}\right)_{L L}$ and predicted $\left(T_{c}-T_{a}\right)_{L L}$ values calculated by the two-variable models were statistically significant at $P=0.05$ or $P=0.01$ except for those that were fit to creeping bentgrass. When the three-variable empirical models were employed, predictive capability rose to 62 , 62 , and $64 \%$, respectively.

Surprisingly, models developed from pooled data slightly outperformed the cultivar specific models across most levels of model complexity. While demonstrating greater predictive capability than the one- or two-variable empirical models, the energy balance approach using cultivar specific $r_{\mathrm{a}}$ and $r_{\mathrm{c}}$ terms accounted for less variation than the three-variable empirical models.

Deviation of the slope of the equation from a value of one is an indication of bias. The average slope of the line relating actual $\left(T_{c}-T_{a}\right)_{I L}$ to predicted $\left(T_{c}-T_{a}\right)_{L L}$
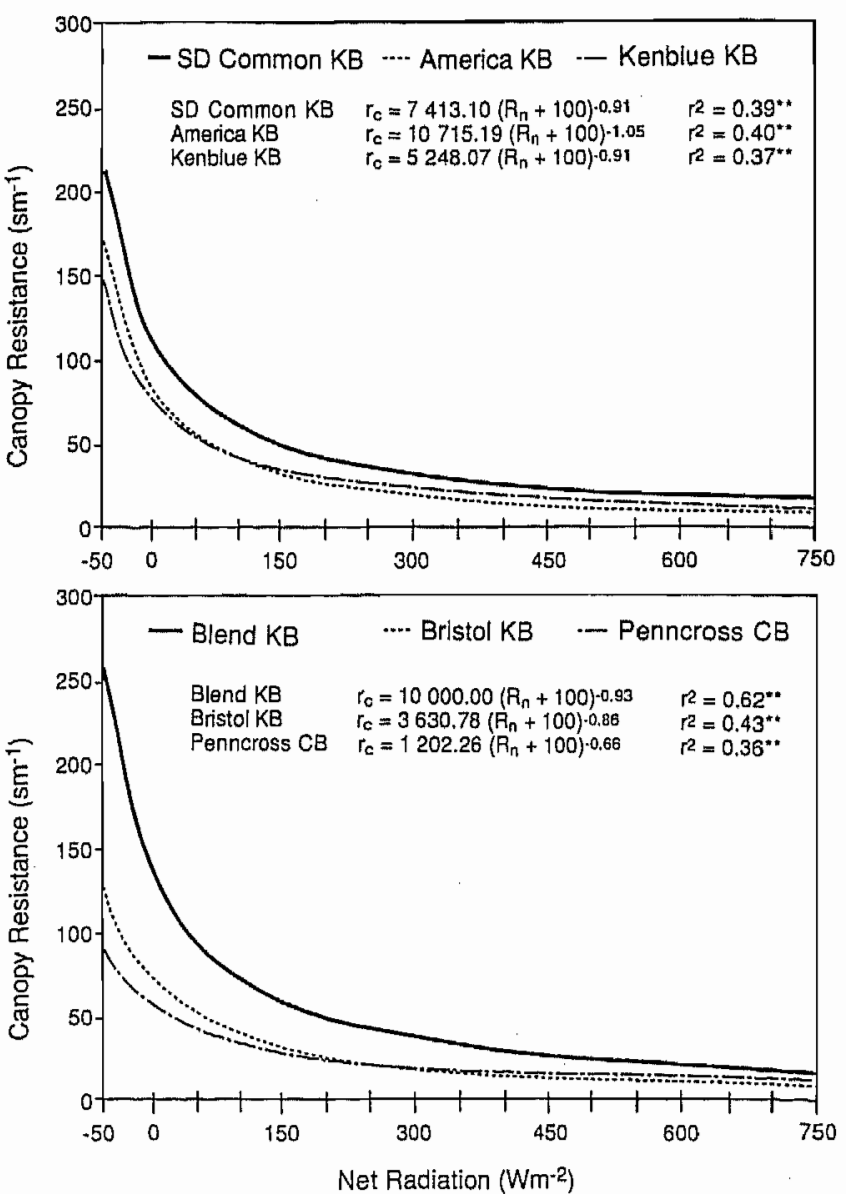

Fig. 2. Relationship between predicted canopy resistance and net radiation for South Dakota Common Kentucky bluegrass (KB), America KB, and Kenblue KB, a blend of KB, Bristol $\mathrm{KB}$, and Penncross creeping bentgrass (CB). 
Table 4. Coefficients of determination and slopes of equations generated by regression of actual canopy-air temperature difference of nonwater-stressed turfgrass on values calculated by prediction equations.

\begin{tabular}{|c|c|c|c|c|c|c|c|}
\hline \multirow[b]{4}{*}{$\begin{array}{c}\text { Model } \\
\text { complexity }\end{array}$} & \multirow[b]{4}{*}{ Statistic } & \multicolumn{6}{|c|}{ Test cultivar/species } \\
\hline & & \multirow{2}{*}{\multicolumn{3}{|c|}{$\begin{array}{c}\text { Kenblue } \\
\text { Kentucky bluegrass } \\
\text { Model type }\end{array}$}} & \multirow{2}{*}{\multicolumn{3}{|c|}{$\begin{array}{l}\text { Penncross } \\
\text { creeping bentgrass } \\
\text { Model type }\end{array}$}} \\
\hline & & & & & & & \\
\hline & & $\begin{array}{c}\text { All } \\
\text { bluegrass } \\
\text { model }\end{array}$ & $\begin{array}{l}\text { Kenblue } \\
\text { model }\end{array}$ & $\begin{array}{c}\text { All } \\
\text { turfgrass } \\
\text { model }\end{array}$ & $\begin{array}{c}\text { All } \\
\text { bluegrass } \\
\text { model }\end{array}$ & $\begin{array}{l}\text { Penncross } \\
\text { model }\end{array}$ & $\begin{array}{c}\text { All } \\
\text { turfgrass } \\
\text { model }\end{array}$ \\
\hline $\begin{array}{l}\text { Vapor pressure } \\
\text { deficit (VPD) }\end{array}$ & $\begin{array}{l}I^{2} \\
\text { Slope }\end{array}$ & $\begin{array}{r}<0.01 \\
0.10\end{array}$ & $\begin{array}{r}<0.01 \\
0.10\end{array}$ & $\begin{array}{r}<0.01 \\
0.10\end{array}$ & $\begin{array}{r}0.02 \\
-0.35\end{array}$ & $\begin{array}{r}0.02 \\
-0.25\end{array}$ & $\begin{array}{r}0.02 \\
-0.32\end{array}$ \\
\hline $\begin{array}{l}\text { VPD + Net } \\
\text { radiation }\left(\mathbf{R}_{n}\right)\end{array}$ & $\begin{array}{r}r^{2} \\
\text { Slope }\end{array}$ & $\begin{array}{l}0.12^{*} \\
0.90\end{array}$ & $\begin{array}{l}0.12^{*} \\
0.90\end{array}$ & $\begin{array}{l}0.12^{*} \\
0.87\end{array}$ & $\begin{array}{l}0.09 \\
0.98\end{array}$ & $\begin{array}{l}0.05 \\
0.64\end{array}$ & $\begin{array}{l}0.08 \\
0.91\end{array}$ \\
\hline $\begin{array}{l}\text { VPD }+\mathbf{R}_{n} \\
+ \text { Windspeed (WS) }\end{array}$ & $\begin{array}{l}r^{2} \\
\text { Slope }\end{array}$ & $\begin{array}{l}0.70 * * \\
1.10\end{array}$ & $\begin{array}{l}0.70^{* *} \\
0.95\end{array}$ & $\begin{array}{l}0.69^{* *} \\
1.09\end{array}$ & $\begin{array}{l}0.76^{* *} \\
1.33\end{array}$ & $\begin{array}{l}0.75^{* *} \\
1.16\end{array}$ & $\begin{array}{l}0.76^{* *} \\
1.30\end{array}$ \\
\hline $\begin{array}{l}\text { Energy balance } \\
\text { equation }\end{array}$ & $\begin{array}{l}r^{2} \\
\text { Slope }\end{array}$ & & $\begin{array}{l}0.60 * * \\
0.76\end{array}$ & & & $\begin{array}{l}0.71 * * \\
0.97\end{array}$ & \\
\hline
\end{tabular}

*,** Significant at 0.05 and 0.01 probability levels respectively.

was 1.06 for the three-variable empirical model. On creeping bentgrass, equations developed from data pooled from all grasses or from the five Kentucky bluegrasses caused a higher degree of bias in predicted $\left(T_{c}-T_{a}\right)_{L L}$ values than those developed specifically from creeping bentgrass data. The bias introduced to predicted $\left(\mathrm{T}_{\mathrm{c}}-\right.$ $\left.T_{\mathrm{a}}\right)_{L L}$ by the three-variable empirical model was minimal compared with that introduced by the energy balance approach (slope $=0.69$ ). The poor predictive capability of the energy balance approach in combination with the large bias it introduced to predicted $\left(\mathrm{T}_{\mathrm{c}}-\mathrm{T}_{\mathrm{a}}\right)_{\mathrm{LL}}$ values was unexpected, and is not easily explained.

In theory, the complete energy-balance approach should provide a more accurate prediction of $\left(T_{c}-T_{a}\right)_{L L}$, however, our method of use of the equation involves an additional level of calculation than the three first-order regression models that it was measured against. Any errors in calculating $r_{a}$ are further propagated through calculation of the predictive relationships between $r_{\mathrm{c}}$ and $R_{\mathrm{n}}$. The energy-balance approach to predicting $\left(\mathrm{T}_{\mathrm{c}}-\right.$ $\left.\mathrm{T}_{\mathrm{a}}\right)_{\mathrm{LL}}$ is more theoretically sound than an empirical approach utilizing least squares regression.

Single-variable models containing VPD as the only independent variable have been the most wide spread type of equations utilized for predicting $\left(T_{c}-T_{a}\right)_{L L}$ in CWSI calculation. The results of this research concur with those of Horst et al. (1989) and Smith et al. (1986), which indicate that more complex models are necessary for accurate prediction of $\left(\mathrm{T}_{c}-\mathrm{T}_{\mathrm{a}}\right)_{L L}$ in areas where WS, VPD, and $R_{\mathrm{n}}$ are highly variable. Based on work performed on an independent data set, Smith et al. (1986) found the complete energy-balance approach with $r_{\mathrm{a}}$ ard $r_{c}$ as dynamic components to be more satisfactory in predicting $\mathrm{T}_{\mathrm{c}}-\mathrm{T}_{\mathrm{a}}$ of nonwater-stressed wheat (Triticum aestivum L. emend. Thell.) than empirical models containing VPD and VPD plus $R_{n}$ or energy-balance models in which $r_{\mathrm{c}}$ and $r_{\mathrm{a}}$ or only $r_{\mathrm{a}}$ were kept constant at their mean value. We did not find the complete energy-balance model with $r_{\mathrm{a}}$ and $r_{\mathrm{c}}$ dynamic to be more satisfactory than the three-variable linear model involving VPD, $R_{n}$, and WS.

The most powerful model for accurate prediction of $\left(T_{c}-T_{a}\right)_{L L}$ in this study was the three-variable linear model that used VPD, $R_{n}$, and WS. A single model of this type was satisfactory across five Kentucky bluegrass cultivars. A general model applied across Kentucky bluegrass and creeping bentgrass in this study introduced bias when used on creeping bentgrass, possibly indicating that a separate model was necessary on creeping bentgrass. Work by Horst et al. (1989) suggested that baselines used in an empirical approach to CWSI calculation were likely species $\times$ cultural regime $\times$ seasonal condition specific. Further testing of the models developed in this study at different locations on various grasses managed under different cultural regimes could provide more information on the limitations of the empirical approach to CWSI calculation on turfgrass.

\section{ACKNOWLEDGMENTS}

The authors wish to express their appreciation for the statistical assistance provided by the late Dr. Samuel Carmer, Professor of Biometric, Univ. of Illinois and partial financial support of this research by the Illinois Turfgrass Foundation.

\section{REFERENCES}

Beard, J.B. 1985. An assessment of water use by turfgrasses. p. 45-60. In V.A. Gibeault and S.T. Cockerham (ed.) Turfgrass water conservation. Div. of Agric. and Nat. Resour. Univ, of California. Pub. 21405. Univ. of California, Oakland.

Carrow, R.N. 1985. Soil/water relationships in turfgrass. p. 85 102. In V.A. Gibeault and S.T. Cockerham (ed.) Turfgrass water conservation. Div. of Agric. and Nat. Resour. Univ. of California. Pub. 21045. Univ. of California, Oakland.

Denmead, O.T., and B.D. Millar. 1976. Field studies of the conductance of wheat leaves and transpiration. Agron. J. 68:307 311.

Fritschen, L., and K. Mullins. 1965. Miniature net radiometer instruction manual. USDA Water Conservation Laboratory Report 5. USDA-ARS, Phoenix, AZ.

Hattfield, J.L. 1985. Wheat canopy resistance determined by energy balance techniques. Agron. J. 77:279-283.

Horst, G.L., J.C. O'Toole, and N.B. Dunning. 1987. Turfgrass canopy temperatures and resistances. p. 135. In Agronomy Abstracls ASA, Madison, WI.

Horst, G.L., and J.C. O'Toole, and K.L. Faver. 1989. Seasonal and species variation in baseline functions for determining crop water stress indices in turfgrass. Crop Sci. 29:1227-1232.

Idso, S.B., R.D. Jackson, P.J. Pinter, Jr., R.J. Reginato, and J.L. Hatfield. 1981a. Normalizing the stress-degree-day parameter for environmental variability. Agric. Meteorol. 24:45-55.

Idso, S.B., R.J. Reginato, D.C. Reicosky, and J.L. Hatfield. $1981 \mathrm{~b}$. Determining soil-induced plant water potential depressions in alfalfa by means of infrared thermometry. Agron. J. $73: 826-830$. 
Jackson, R.D., S.B. Idso, and P.J. Pinter, Jr. 1981. Canopy temperature as a crop water stress indicator. Water Resour. Res. 17:1133-1138.

Johns, D., C.H.M. van Bavel, and J.B. Beard. 1981. Determination of the resistance to sensible heat flux density from turfgrass for estimation of its evapotranspiration rate. Agric. Meteorol. 25:15-25.

Johns, D., J.B. Beard, and C.H.M. van Bavel. 1983. Resistances to evapotranspiration from a St. Augustinegrass turf canopy. Agron. J. 75:419-422.

Martin, D.L. 1990. Crop water stress index models for cool season turfgrasses. Ph.D. diss. Univ. of Illinois, Urbana (Diss. Abstr. AAC9026263).
Monteith, J.L. 1973. Principles of environmental physics. American Elsevier, New York.

Shearman, R.C. 1985. Turfgrass culture and water use. p. 6170. In V.A. Gibeault and S.T. Cockerham (ed.) Turfgrass water conservation. Div. of Agric. and Nat. Resour. Univ. of California. Pub. 21405. Univ. of California, Oakland.

Smith, R.C.G., H.D. Barrs, and J.L. Steiner. 1986. Alternative models for predicting the foliage-air temperature difference of well irrigated wheat under variable meteorological conditions: I. Derivation of parameters. II. Accuracy of predictions. Irrig. Sci. $7: 225-236$.

Throssell, C.S., R.N. Carrow, and G.A. Milliken. 1987. Canopy temperature based irrigation scheduling indices for Kentucky bluegrass turf. Crop Sci. 27:126-131. 